\title{
Focus on the Middle East
}

\section{The Secret History of al Qaeda}

ABDEL BARI ATWAN

"Deeply researched, well reported and full of interesting and surprising analyses. It demands to be read."

-Peter Bergen, author of Holy War, Inc. and The Osama BIn Laden I Know

$\$ 24.95$ cloth
The State of the Middle East

An Atlas of Conflict and Resolution

DAN SMITH

This innovative and information-packed volume combines clear, analytical text with full-color maps and graphics to provide a comprehensive and accessible guide to the region today. $\$ 50.00$ cloth, $\$ 19.95$ paper

At bookstores or $(800)$ 822-6657 - www.ucpress.edu 


\section{WHAT'S NEW IN POLITICAL SCIENCE?}

\author{
Feminist Methodologies for \\ International Relations \\ Edited by Brooke A. Ackerly, \\ Maria Stern, and lacfull True \\ 575,00: $4 \mathrm{t}: 0-521-86715-2 \times 330 \mathrm{pp}$ \\ $\$ 29.93:$ p. 0.521-67835.8
}

\section{The Primacy of Politics}

Social Democracy and the Making of

Europe's Twenteth Century

Sheri E, Berman

\$65.00: Hb: 0.521-81799-4: 232pp

\$2399: Pb: 0.521-521100.6

\section{Democratic Processes and Financial Markets \\ Pricing Politics \\ William T. Bernhard and \\ David Leblang \\ \$70.00: Hb:0.521+86122-5: 272pp \\ $\$ 24,99: 96: 0-521-67838-2$}

\section{Argument and Authority in \\ Early Modern England}

The Presupposition of oaths and offices

conal condren

5os $140: 0521 \times 85908$ s a12pp

\section{Human Rights in}

International Relations

Second Edition

David P forsy the

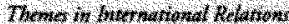

$075.00 \cdot 10,0521796560,3,29800$

124.96. $+6.0521 .68427 \%$

\section{Design for a New Europe}

lohs cillinghan

$55000,46,0,52186694,4,2800 \%$

$019.59 \cdot 06.0 .5 \times 1.686644$

\section{Bratil since 1980}

francisco Vidal Luna and

Nebert s Wen

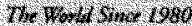

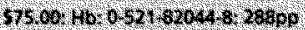

12158276,0524527449

\section{Age in the Welfare State}

The orights of Socdat spending on fersloners Workers and Children

Jila Lyach

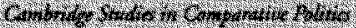

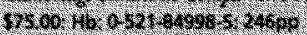

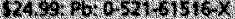

\author{
Economic Autonomy and \\ Democracy \\ Hybrid Regimes in Russia and \\ Kyrgyzstan \\ Kelly M. McMann \\ \$75.00: $\mathrm{Hb}: 0-521-85761.9278 \mathrm{pp}$
}

\section{The United Nations}

Development Programme

A Setter Way?

Craig N. Murphy

\$75.00*: $\mathrm{Hb}: 0.521 .86469 .0: 384 \mathrm{po}$

$289.93^{*}: \mathrm{Pb}: 0.521 .68316 \cdot 5$

\section{A History of Modern Palestine}

One Land, Two Peoples

Second Edition

llan Pappe

75.00 + Hb: $0.521+864682$ 2 384ap

24.99:060.52168315?

\section{The Voluntary}

\section{Environmentalists}

Green Chos, 100 14001, and Volumary

Environmentol Regulations

Aseem Prokash and

Mathew Potosk

58000 H6. $0.521 .66041,5,19800$

$529.93+$ ph. 0.521 .67726

\section{Behavioral Social Choice}

probutistic Nodels statistical

hrerence and Apolications

Michel Regorwetter

Gemard Groman, A. A., Marley and Na Tsetin.

570.00, wh: $0.521,829682,256 \mathrm{po}$

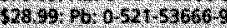

\section{International Relations}

The Patri Nor taken

Thonas o sdioention

$47,06,46,65 \times 1,66260.9 .37600$

62504 pb. 6.521.68150

\section{Architects of}

Poltical Change

Consthutional owandaries ard

sodal Crolat theary

Noman schotiele

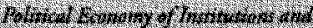

$1+24,6 \times 1$

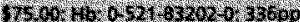

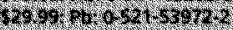

Multiparty Democracy

Elections and Legistative Politics Norman Schofield and ltai sened

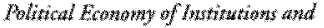
Decisiont

\$70.00; Hb: 0-521-45035-7:2485p \$24.99: Pb: 0.521 .456584

\section{Faith in Moderation}

Islamist Parties in Jordan and Yemen Jillan schwedler

\$80.00: Hb: 0.521-85113-0: 2760p

\section{Candidate Strategies} and Electoral Competition in the Russian Federation

Democacy without Foundation

negin smyth

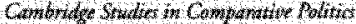
580.00 Hb $0521184690-0.2600 \mathrm{p}$

\section{Resisting the State}

Netom and Retrendiment in Tost Soviet Russia

Kathryn Stoner Welss

$\$ 75.00,16,0.521 \times 82463 \times 182 \mathrm{pp}$

Rationality and the ideology of Disconnection

Midhad Tylor

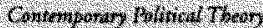

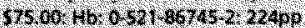
$126,99.90,0,521,687047$

\section{The United Nations,}

Feace and Security from collective security to the Responsibilivy to Protect farmesh thakut

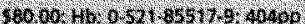
52. 99.6010521671256

\section{Crucibles of}

Poltical Loyalty

crurch instivens and

Electoral Conthuity in Hongary. tason Witienberg

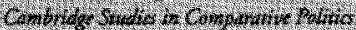

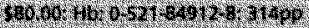

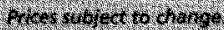




\section{Breeding Bin Ladens}

America, Islam, and the Future of Europe

\section{Zachary Shore}

"Zachary Shore realized earlier than most the potentially huge importance of the religious revival among young Muslims in Europe. The interviews and other evidence in his scrupulously researched and lucidly written book constitute powerful evidence of a disturbing trend. It is not simple hatred of the United States so much as ambivalence about Western society as a whole that has driven these teenagers and twenty-somethings into the arms of the extremists."

-Niall Ferguson, Harvard

University

$\$ 25.00$ hardcover

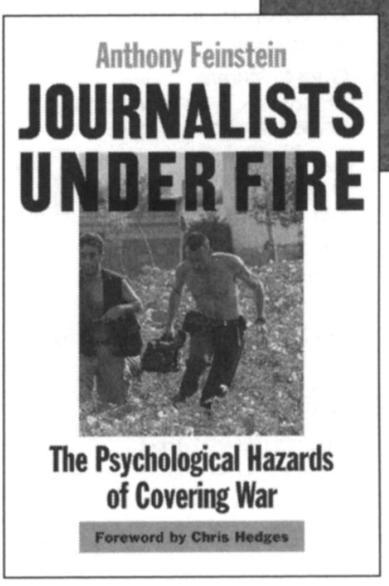

BREEDING

BINLADENS

AND $\mathrm{THE}$

Futupe br ELROF

ZACHARY SHERE

\section{Great Powers} and Geopolitical Change Jakub J. Grygiel

The mountains of Afghanistan and the scorching sand storms of Iraq have provided stark reminders that geographical realities continue to have a profound impact on the success of military campaigns. Jakub J. Grygiel brings to light the importance of incorporating geography into grand strategy. He argues that states can increase and maintain their position of power by pursuing a geostrategy that focuses on control of resources and lines of communication.

$\$ 47.00$ hardcover
"Dr. Feinstein has provided us with

research that is a chilling reminder that war journalists are human, as well as a searing indictment of major news conglomerates who have refused to acknowledge or address the suffering of their own." —Chris Hedges, former New York Times war correspondent and author of War Is a Force that Gives Us Meaning $\$ 25.00$ hardcover 


\section{Iran's Nuclear Ambitions Shahram Chubin}

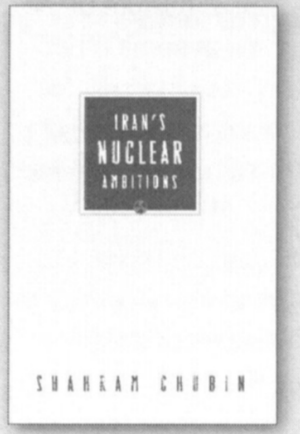

September 2006

Paper 0-87003-230-5 $\$ 12.95$

Cloth $0-87003-231-3 \$ 32.95$
"The strategic and political determinants of Iran's nuclear policy are complicated and frequently misunderstood. Chubin's study is the definitive work on the subject and should be required reading for U.S. and European decision makers as they struggle to prevent the Iranian bomb from becoming a reality."

- Geoffrey Kemp, The Nixon Center

"Shahram Chubin's account of Iran's nuclear ambitions is accurate, thorough and thoughtful. Its greatest merit is its emphasis that Iran's aims are above all political. That does not make them any less difficult or dangerous; but understanding this point is a good starting place for tackling the problem."

- Robert Cooper, Director General for External and PoliticoMilitary Affairs, Council of the European Union 


\section{Runaway State-Building}

Patronage Politics and Democratic

Development

Conor O'Dwyer

"A theoretically sophisticated comparative study which illuminates both convergence and divergence in the Euro-

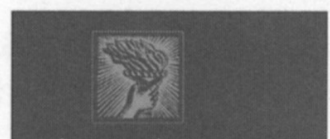

Electoral Systems and Democracy
Electoral Systems and Democracy edited by Larry Diamond and Marc F. Plattner

As the number of democracies has increased around the world, a heated debate has emerged

pean Union's new accession states and helps us all to better understand when and why the European Union does - or does not-matter."

-Alberta Sbragia, director, European Union Center of Excellence $\$ 49.95$ hardcover

\section{Informal Institutions and Democracy}

Lessons from Latin America edited by Gretchen Helmke and Steven Levitsky

This volume analyzes the function of informal institutions in Latin America and how they support or weaken democratic governance. Drawing from a wide range of examples-including the Mexican dedazo clientelism in Brazil, legislative "ghost coalitions" in Ecuador, and elite powersharing in Chile-the contributors examine how informal rules shape the performance of state and democratic institutions, offering fresh and timely insights into problems of governability, "unrule of law," and the absence of effective representation, participation, and accountability.

RUNAWAY STATEBUILDING

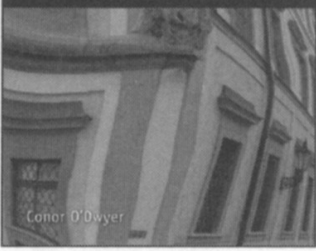

among experts about which system best promotes the consolidation of democracy. Is proportional representation, a majoritarian system, a mixture of the two, or some other system the best for new democracies? This book compares the experiences of diverse countries, from Latin America to southern Africa, from Uruguay, Japan, and Taiwan to Israel, Afghanistan, and Iraq. A Journal of Democracy Book $\$ 18.95$ paperback

\section{Global Social Change}

Historical and Comparative

Perspectives

edited by Christopher Chase-Dunn and Salvatore J. Babones

The essays in Global Social Change explore globalization from a worldsystems perspective, offering insights into globalization's gradual and uneven growth throughout the course of human social evolution.

\$26.95 paperback

$\$ 25.00$ paperback 


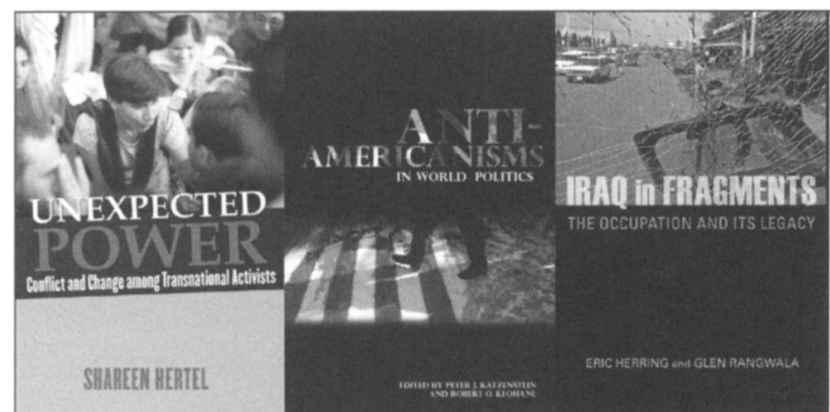

UNEXPECTED POWER

Conflict and Change among

Transnational Activists

Shareen Hertel

"A signal contribution to the growing body of social-science literature on international policy campaigns."

-Lance Compa, Cornell University 176 PAGES, \$17.95 PAPER/\$45.00 CLOTH AN ILR PRESS BOoK

\section{PEACE AT ANY PRICE}

How the World Failed Kosovo

lain King and Whit Mason

"A frank account of the international community's experience in Kosovo and a valuable guide to building stable societies in war-torn regions."

-Dana Eyre, USIP 328 PAGES, \$27.95 CLOTH CRISES IN WORLD POUTICS

\section{GLOBAL BIOPIRACY}

Patents, Plants, and Indigenous Knowledge Ikechi Mgbeoji

"Mgbeoji masterfully unearths the technicalities and subtleties of the issue."

$$
\begin{array}{r}
\text {-James T. Gathii, Albany Law School } \\
336 \text { PAGES, \$22.95 PAPER }
\end{array}
$$

New in Paperback

THE DEFEAT OF SOLIDARITY

Anger and Politics in Postcommunist Europe David Ost

"Goes against the grain, insisting that class is still a useful, indeed vital, sociopolitical category."
IRAO IN FRAGMENTS

The Occupation and Its Legacy

Eric Herring and

Glen Rangwala

"A first-rate study of the consequences for Iraq of the US-led invasion and occupation of the country."

-Charles Tripp, SOAS 368 PACES, $\$ 27.95$ CLOTH Crises in World Politics

PLAYING THE MARKET

A Political Strategy for Uniting Europe, 1985-2005

Nicolas Jabko

“The best book I've seen about the development of the single market and its repercussions for the integration process."

-Daniel Kelemen, Oxford University 224 PAGES, \$19.95 CLOTH Cornell Studies in Political Economy

New in Paperback

DANGEROUS SANCTUARIES

Refugee Camps, Civil War, and the

Dilemmas of Humanitarian Aid

Sarah Kenyon Lischer

"Will certainly shape academic and policy debates for years to come."

-Journal of Peace Research 222 PAGES, \$19.95 PAPER

Cornell Studies in Security Affairs

ANTI-AMERICANISMS IN WORLD POLITICS edited by Peter J. Katzenstein and

Robert O. Keohane

"Makes a significant contribution by explicitly comparing the intensity of anti-American views across countries and regions."

-Ido Oren, University of Florida 368 PAGES, \$24.95 PAPER/\$55.00 CLOTH Cornell Studies in Political Economy

New in Paperback

HEALTHY DEMOCRACIES

Welfare Politics in Taiwan and South Korea Joseph Wong

"A most valuable contribution to the growing literature on welfare-state development."

-Democratization 222 PAGES, \$21.00 PAPER

\section{NEW FROM Cornell University Press}

www.cornellpress.cornell.edu | 1-800-666-2211 


\section{UNIVERSITY OF PENNSYLVANIA PRESS}

\section{TRAPPED IN THE WAR ON TERROR Ian S. Lustick}

Ian S. Lustick debunks the myths sustaining the War on Terror and demonstrates how, in fighting such a war, we become our own worst enemy.

The first principle of terrorism is to understand that the weak win by exploiting the strength of the powerful. When 9/11 terrorists with box cutters hijacked American airliners, they transformed America's preeminent transportation system into a devastating weapon of attack. They also set a trap with the promise of revenge and security as the bait. The hijackers' biggest victory was to goad our government into taking the bait by unleashing the War on Terror. The worry, witch-hunt, and waste that have ensued are, according to Lustick, destroying American confidence, undermining our economy, warping our political life, and isolating us from our international allies.

TRAP P E D in the WAR on

TERROR

2006 | 200 pages | Cloth | \$24.95

Available from bookstores or call 800-537-5487 